\title{
Cemented calcar replacement versus cementless hemiarthroplasty for unstable intertrochanteric femur fractures in the elderly
}

\author{
Deniz Çankaya, M.D., Bülent Özkurt, M.D., Abdullah Yalçın Tabak, M.D. \\ Department of Orthopaedics and Traumatology, Ankara Numune Training and Research Hospital, Ankara
}

\begin{abstract}
BACKGROUND: Unstable intertrochanteric fractures remain a challenging problem in elderly individuals due to high failure rates associated with internal fixation. Hemiarthroplasty is one treatment option for intertrochanteric femur fractures in elderly patients. The aim of the present study was to compare the reliability of cementless and cemented hemiarthroplasty for unstable intertrochanteric femur fractures in elderly patients.
\end{abstract}

METHODS: Elderly patients with AO type 3I-A2 intertrochanteric femur fractures were treated with cemented ( $\mathrm{n}=40$ ) or cementless $(n=46)$ hemiarthroplasty. Duration of surgery, amount of blood loss and blood transfusion, Harris hip scores, rate of loosening of the femoral component, duration of hospital stay after surgery and mortality rates were recorded.

RESULTS: There were no significant differences between the groups in length of hospital stays, Harris hip scores, amount of blood transfusions, implant loosening and follow-up mortality rates. Walking ability was better in the cemented group in the early follow-up period. Duration of surgery, amount of blood loss and perioperative mortality rates were significantly lower in the cementless group than in the cemented group.

CONCLUSION: Cementless hemiarthroplasty is a reliable treatment choice for unstable intertrochanteric femur fractures in elderly patients with early mobilization, acceptable functional results, low implant loosening rates, shorter surgery time, lesser blood loss and lower perioperative mortality rate.

Key words: Cementless hemiarthroplasty; elderly; intertrochanteric femur fractures; mortality.

\section{INTRODUCTION}

Hip fractures present a common source of morbidity and mortality among elderly people worldwide. Globally, the mean age of the population is increasing, and the number of hip fractures is expected to triple in the next 50 years. ${ }^{[1]}$ Intertrochanteric hip fractures are extracapsular fractures common in elderly people with poor bone quality. ${ }^{[2]}$ Classifications of these fractures are unreliable and therefore not useful in determining treatments. In general, fractures with comminution of the posteromedial cortex and subtrochanteric extension

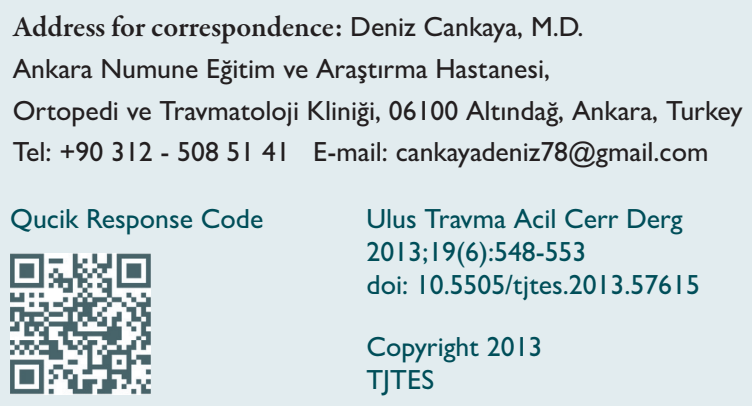

are considered unstable. ${ }^{[3]}$ The treatment of unstable intertrochanteric femur fractures is very challenging and is still a matter of discussion, especially in elderly patients. ${ }^{[4]}$

Studies comparing internal fixation and hemiarthroplasty for unstable intertrochanteric femur fractures in elderly patients state that hemiarthroplasty is an alternative treatment with earlier mobilization and the same functional outcome compared to internal fixation. ${ }^{[4,5]}$ Although hemiarthroplasty has become popular for intertrochanteric femur fractures in elderly patients, there is no consensus whether cementless or cemented hemiarthroplasty is a better option. Cementation is associated with an increase in intramedullary pressure, consequently leading to fat embolization, which increases the mortality rates in cemented hemiarthroplasty. Bone cement implantation syndrome is a challenging problem, especially in patients with multiple comorbidities. Several studies examined the effects of cementing on morbidity and mortality with controversial results and pointed out the need for future studies. ${ }^{[6-9]}$

Although the outcomes of cemented and cementless 
hemiarthroplasty were reported individually, ${ }^{[2,10-12]}$ to our knowledge, there has been no study comparing cemented and cementless hemiarthroplasty for intertrochanteric femur fractures in elderly patients. In the present study, we aimed to compare the reliability of cementless and cemented hemiarthroplasty for unstable intertrochanteric femur fractures in elderly patients.

\section{MATERIALS AND METHODS}

Between 2008 and 2010, 86 patients with AO type 31-A2 intertrochanteric femur fractures were included in this prospective study. Patients with pathological fractures, previous contralateral hip fractures, stable fractures and reverse oblique fractures were excluded from the study. Of the eligible patients, 46 of them underwent cemented hemiarthroplasty (Group I), and 40 of them underwent cementless hemiarthroplasty (Group II). Group I included 10 male and 36 female patients with an average age of 78 years (range 6695 years). Group II included 8 male and 32 female patients with an average age of 76 years (range 65-92 years). There were no significant differences between the groups in age and gender (Table I).

The comorbidity scores of the patients according to the American Society of Anesthesiologists (ASA) criteria were recorded before the surgery. One operating surgeon performed the cemented and cementless operations with the same surgical technique. In Group I, cemented calcar replacement stems designed for proximal femur (Biomet Inc. Warsaw, IN, USA) were used (Figure I). In Group II, PPF and taperloc femoral stems of the same company (Biomet Inc. Warsaw, IN, USA) were used (Figure 2). The modified Watson-Jones anterolateral approach with the same surgical technique was used for all patients. According to the amount of displacement and bone quality, displaced trochanteric fractures were secured by Dall-Miles cable or pds suture in both techniques. Surgery time, amount of blood loss and blood transfusion were recorded. The perioperative interval was considered as the time between hospitalization and 72 hours postoperatively.
Follow-up visits were performed at 6 weeks, then at 3, 6 and 12 months and every year thereafter. Harris hip scores and walking ability of the patients were recorded during followup visits. Hip radiographs were evaluated for loosening of the femoral stem. Any change in the position of the stem, or a continuous radiolucent line wider than $2 \mathrm{~mm}$ at the bone-cement or bone-implant interface in at least two Gruen zones were accepted as loosening. Mortality rates of the groups in the follow-up period were recorded and reported as the perioperative, 3-month, I-year and 2-year mortality rates.

\section{Statistical Analysis}

Statistical calculations were performed with SPSS 13.0 (SPSS Inc, Chicago IL, USA) and the results are expressed in mean and standard deviation. Comparisons between the groups were done with the Student t-test and chi-square test. A p value $<0.05$ was considered to indicate a statistically significant difference.

\section{RESULTS}

In Group I, six patients died perioperatively. During the follow-up period, 18 patients in Group I and 17 patients in Group II died. After 2 years of follow-up, 22 patients in Group I and 23 patients in Group II were alive. The mean follow-up period in Group I and II were 38 months (range 24-5 I months) and 32 months (range 24-45 months), respectively. The number of patients with lower ASA scores (ASA I or 2) and higher ASA scores (ASA 3 or 4) were $17 / 29$ and $11 / 23$, respectively. There was no significant difference between the groups in comorbidy scores $(p=0.600)$.

The mean surgical time was $89.13( \pm 8.51)$ minutes for Group I and $83.10( \pm 9.50)$ minutes for Group II. The surgical time was significantly shorter in Group II $(p=0.004)$. The average number of units of packed red cells (PRCs) transfused were I.I0 and I.24 in Group I and Group 2, respectively. Postoperative transfusion rates were similar in the groups $(p=0.338)$. The amount of postoperative drainage was 540 ( \pm I l 9$) \mathrm{ml}$ and 469

Table I. Demographic and clinical data of the patients

\begin{tabular}{lccc}
\hline & Cemented group & Cementless group & $p$ \\
\hline Number & 46 & 40 & \\
Age (years) & $78(7.1 \mathrm{I})$ & $76(7.52)$ & 0.317 \\
Sex (Female / Male) & $36 / 10$ & $32 / 8$ & 0.843 \\
ASA I-2/3-4 & $17 / 29$ & $17 / 23$ & 0.600 \\
Operating times (minutes) & $89(8.5 \mathrm{I})$ & $83(9.50)$ & 0.004 \\
Blood transfusion (packet) & $1.28(0.72)$ & $1.43(0.68)$ & 0.338 \\
Blood loss (ml) & $540(1 \mathrm{I})$ & $468(131)$ & 0.012 \\
Hospital stay (days) & $9.10(2.34)$ & $9.80(2.45)$ & 0.195 \\
\hline The values are given as the mean and the number of patients with the standard deviation in parentheses.
\end{tabular}



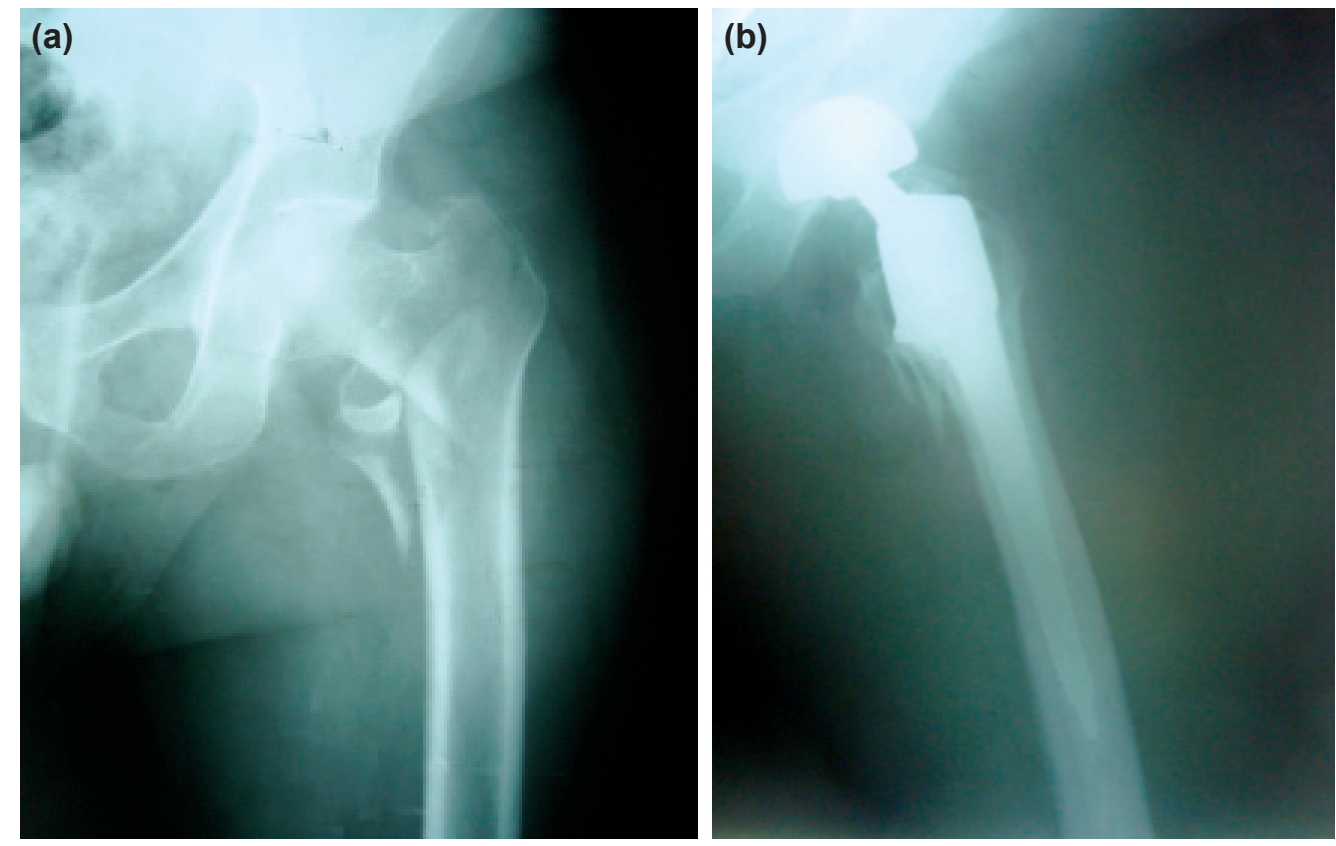

Figure 1. (a) Anteroposterior preoperative radiograph of the patient with unstable intertrochateric fracture and (b) postoperative radiograph after cementless hemiarthroplasty.
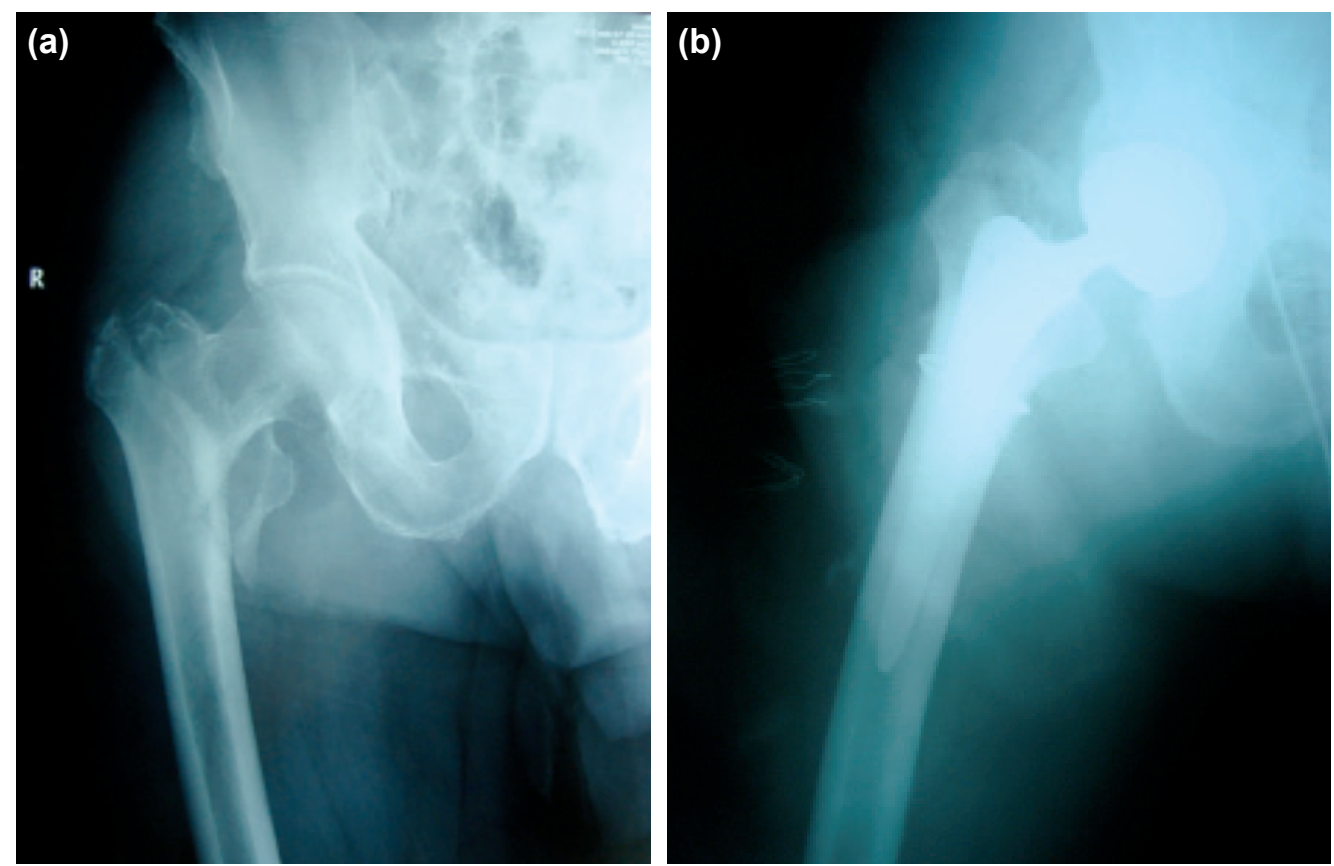

Figure 2. (a) Anteroposterior preoperative radiograph of the patient with unstable intertrochateric fracture and (b) postoperative radiograph after cementless hemiarthroplasty.

$( \pm|3|) \mathrm{ml}$ in Groups I and II, respectively. The amount of postoperative blood loss was significantly lower in Group II $(p=0.012)$. The mean duration of hospital stay was 9.10 days and 9.80 days, respectively $(p=0.195)$. All patients were ambulatory during discharge. The mean Harris hip scores at the 3 -month and I-year follow-ups were $77.13( \pm 5.60)$ and 81.52 $( \pm 6.12)$ for Group I and $75.97( \pm 5.20)$ and $80.81( \pm 6.66)$ for Group II. At the last follow-up, the mean Harris hip scores increased to $83.27( \pm 6.33)$ and $82.78( \pm 5.88)$, respectively.
There were no significant differences between the groups regarding the Harris hip scores during the follow-up period (Table 2).

Before surgery, 35 patients of Group I and 30 patients of Group II walked without support $(p=0.907)$. At the 3 -month follow-up, the number of patients who were able to walk without support was 12 and 5, respectively. Group II had a significantly better outcome in walking ability $(p=0.039)$. After 
Table 2. Functional outcome during the follow-up

\begin{tabular}{|c|c|c|c|}
\hline & Cemented group & Cementless group & $p$ \\
\hline \multicolumn{4}{|l|}{ Harris Hip Score (100) } \\
\hline HHS at 3 months & $77.13(5.59)$ & $75.97(5.20)$ & 0.397 \\
\hline HHS at 12 months & $81.52(6.21)$ & $80.81(6.66)$ & 0.695 \\
\hline HHS at 24 months & $83.27(6.33)$ & $82.76(5.88)$ & 0.789 \\
\hline \multicolumn{4}{|c|}{ Walking without support (WWS) } \\
\hline Pre-operative WWS & $35 / 46$ & $30 / 40$ & 0.907 \\
\hline WWS at 3 months & $|2 / 3|$ & $5 / 32$ & 0.039 \\
\hline WWS at 12 months & $14 / 25$ & $1 \mathrm{l} / 27$ & 0.271 \\
\hline WWS at 24 months & $14 / 22$ & $13 / 23$ & 0.626 \\
\hline
\end{tabular}

Table 3. Mortality rates in follow-up

\begin{tabular}{|c|c|c|c|c|c|}
\hline & \multicolumn{2}{|c|}{ Cemented group } & \multicolumn{2}{|c|}{ Cementless group } & \multirow[t]{2}{*}{$p$} \\
\hline & $\mathbf{n}$ & $\%$ & $\mathbf{n}$ & $\%$ & \\
\hline Perioperative & $6 / 46$ & 13 & $0 / 40$ & 0 & 0.028 \\
\hline $0-3$ months & $9 / 40$ & 23 & $8 / 40$ & 20 & 0.785 \\
\hline 3-12 months & $6 / 31$ & 19 & $5 / 32$ & 16 & 0.697 \\
\hline I2-24 months & $3 / 25$ & 12 & $4 / 27$ & 15 & 0.766 \\
\hline
\end{tabular}

The values are given as the number of patients.

the 2-year follow-up, the number of patients who were able to walk without support was 14 and I3, respectively and there was no significant difference between the groups $(p=0.626)$ (Table 2). Radiographs of the operated hip were taken in every follow-up to evaluate loosening of the femoral stem. There was no osteolysis or implant failure, and as displaced fragments were secured, there was no nonunion of trochanteric major fracture in both groups during regular follow-up.

While six patients in Group I died perioperatively, none of the patients died in Group II, and the perioperative mortality rate was significantly higher in Group I compared to that of Group II $(p=0.028)$. The number of deaths was 15 and 13, respectively, at the I-year follow-up. Between the first and the second years, three patients from Group I and four patients from Group II died. Regarding the follow-up mortality rates, there were no significant differences between the groups (Table 3).

\section{DISCUSSION}

As life expectancy increases with better medical care, hip fractures have become a common source of morbidity and mortality worldwide. ${ }^{[I]}$ Hip fractures in elderly patients tend to present significant comminution and displacement due to inevitable osteoporosis in elderly patients. With the involve- ment of the greater and lesser trochanters, unstable intertrochanteric fractures are one of the most complex forms of hip fracture in elderly patients. Additionally, elderly patients have weak/porous bones that do not usually provide adequate purchase for internal fixation, leading to early biomechanical failure. Due to the high rate of failure, the best strategy for the treatment of unstable trochanteric femur fractures in elderly patients is still a matter of debate.

The first endoprostheses used in hip fractures were designed for cementless use, but cemented fixation has become the preferred technique thereafter. ${ }^{[l]}$ Several studies showed that cemented hemiarthroplasty with or without calcar replacement was a good option in elderly patients with intertrochanteric femur fracture. ${ }^{[13-16]}$ As cemented hemiarthroplasty is more commonly used, the effect of cementation on mortality, caused by elevating the intramedullary pressure which leads to fat embolization, has become one of the main concerns of physicians. ${ }^{[6-8,17,18]}$ Contradictory results were obtained in these studies. Elmaraghy et al. ${ }^{[6]}$ suggested that cemented hemiarthroplasty had no effect on the formation of fat emboli, but Christie et al. ${ }^{[7]}$ showed that cemented arthroplasty caused greater and more prolonged embolic cascades than did uncemented arthroplasty. In another study, Donaldson et al. ${ }^{\left[{ }^{[8]}\right.}$ suggested that morbidity and mortality might be minimized by preferring cementless arthroplasty 
in high-risk patients. A review article on 7,774 patients with hip fractures concluded that cemented arthroplasty caused significantly higher mortality. ${ }^{[17]}$ Hossain et al. ${ }^{[18]}$ reported eight cases of perioperative death after cemented hemiarthroplasty in elderly patients. Our results supported these studies, which suggested serious adverse effects of cement on mortality. Among 46 patients in the cemented group, 6 patients died during the perioperative period while there was no death among patients who had cementless hemiarthroplasty. The present study showed that cementation significantly increased the perioperative mortality rate, similar to the majority of the studies in the literature.

As cementless hemiarthroplasty appears to be an alternative treatment choice for intertrochanteric femur fractures in elderly patients, the reliability of cementless hemiarthroplasty in this age group has become the main concern of recent studies. ${ }^{[2,5,10-13]}$ The main argument against cementless hemiarthroplasty was the possible low osseointegration in osteoporotic patients leading to instability of the implant. Two recent studies reported an implant survival rate of about $100 \%$ after total hip arthroplasty after more than 5 years follow-up in patients older than 75 years of age. ${ }^{[19,20]}$ No implant failure was reported in the studies, which evaluated cementless hemiarthroplasty for unstable intertrochanteric fractures in elderly patients. ${ }^{[2,4,5,10,11]}$ Even in cementless modular hip arthroplasty after failed trochanteric fracture fixation, none of the patients required reoperation due to the loosening of femoral prosthesis. ${ }^{[21]}$ Our current study also supported the results reported in the literature and no implant loosening or failure was observed during 2 years follow-up.

To our knowledge, there is no comparative study between cemented and cementless calcar replacement hemiarthroplasty for unstable intertrochanteric fractures in elderly patients. In our current comparative study, we found that cemented hemiarthroplasty was associated with better outcomes only in walking without support during the early follow-up period. However, during the first year of follow-up, this advantage disappeared. Cementless hemiarthroplasty had shorter surgical time and lesser blood loss compared to cemented hemiarthroplasty; however those differences did not alter the transfusion rate. Regarding the functional outcomes, there was no difference between cemented and cementless hemiarthroplasty. The most important result of the present study was the significantly higher perioperative mortality rates after cemented arthroplasty.

\section{Conclusion}

Cementless hemiarthroplasty is a reliable treatment choice for intertrochanteric femur fractures in older age-group patients with early mobilization, acceptable functional results, low implant loosening rates, shorter surgery time, lesser blood loss and lower perioperative mortality rate.

\section{Conflict of interest: None declared.}

\section{REFERENCES}

1. Miyamoto RG, Kaplan KM, Levine BR, Egol KA, Zuckerman JD. Surgical management of hip fractures: an evidence-based review of the literature. I: femoral neck fractures. J Am Acad Orthop Surg 2008;16:596607.

2. Choy WS, Ahn JH, Ko JH, Kam BS, Lee DH. Cementless bipolar hemiarthroplasty for unstable intertrochanteric fractures in elderly patients. Clin Orthop Surg 2010;2:221-6. [CrossRef ]

3. Kaplan K, Miyamoto R, Levine BR, Egol KA, Zuckerman JD. Surgical management of hip fractures: an evidence-based review of the literature. II: intertrochanteric fractures. J Am Acad Orthop Surg 2008;16:665-73.

4. Kim SY, Kim YG, Hwang JK. Cementless calcar-replacement hemiarthroplasty compared with intramedullary fixation of unstable intertrochanteric fractures. A prospective, randomized study. J Bone Joint Surg Am 2005;87:2186-92. [CrossRef ]

5. Kayali C, Agus H, Ozluk S, Sanli C. Treatment for unstable intertrochanteric fractures in elderly patients: internal fixation versus cone hemiarthroplasty. J Orthop Surg 2006;14:240-4.

6. Elmaraghy AW, Humeniuk B, Anderson GI, Schemitsch EH, Richards RR. The role of methylmethacrylate monomer in the formation and haemodynamic outcome of pulmonary fat emboli. J Bone Joint Surg Br 1998;80:156-61. [CrossRef ]

7. Christie J, Burnett R, Potts HR, Pell AC. Echocardiography of transatrial embolism during cemented and uncemented hemiarthroplasty of the hip. J Bone Joint Surg Br 1994;76:409-12.

8. Donaldson AJ, Thomson HE, Harper NJ, Kenny NW. Bone cement implantation syndrome. Br J Anaesth 2009;102:12-22. [CrossRef ]

9. Taylor F, Wright M, Zhu M. Hemiarthroplasty of the hip with and without cement: a randomized clinical trial. J Bone Joint Surg Am 2012;94:577-83. [CrossRef ]

10. Sinno K, Sakr M, Girard J, Khatib H. The effectiveness of primary bipolar arthroplasty in treatment of unstable intertrochanteric fractures in elderly patients. N Am J Med Sci 2010;2:561-8. [CrossRef]

11. Lee YK, Ha YC, Chang BK, Kim KC, Kim TY, Koo KH. Cementless bipolar hemiarthroplasty using a hydroxyapatite-coated long stem for osteoporotic unstable intertrochanteric fractures. J Arthroplasty 2011;26:626-32. [CrossRef ]

12. Rodop O, Kiral A, Kaplan H, Akmaz I. Primary bipolar hemiprosthesis for unstable intertrochanteric fractures. Int Orthop 2002;26:233-7.

13. Haentjens P, Casteleyn PP, De Boeck H, Handelberg F, Opdecam P. Treatment of unstable intertrochanteric and subtrochanteric fractures in elderly patients. Primary bipolar arthroplasty compared with internal fixation. J Bone Joint Surg Am 1989;71:1214-25.

14. Abdelkhalek M, Ali AM, Abdelwahab M. Cemented bipolar hemiarthroplasty with a cerclage cable technique for unstable intertrochanteric hip fractures in elderly patients. Eur J Orthop Surg Traumatol 2013;23:443-8.

15. Kesemenli C, Subaşi M, Arslan H, Kirkgöz T, Necmioğlu S. Treatment of intertrochanteric fractures in elderly patients with Leinbach type endoprostheses. Ulus Travma Derg 2001;7:254-7.

16. Akman S, Sen C, Asik M, Akpinar S, Gedik HK. Our experience with leinbach prosthesis in intertrochanteric femoral fractures. Ulus Travma Acil Cerrahi Derg 1999;5:208-212.

17. Parvizi J, Ereth MH, Lewallen DG. Thirty-day mortality following hip arthroplasty for acute fracture. J Bone Joint Surg Am 2004;86-A:1983-8.

18. Hossain M, Andrew JG. Is there a difference in perioperative mortality 
between cemented and uncemented implants in hip fracture surgery? Injury 2012;43:2161-4. [CrossRef]

19. Berend KR, Lombardi AV, Mallory TH, Dodds KL, Adams JB. Cementless double-tapered total hip arthroplasty in patients 75 years of age and older. J Arthroplasty 2004;19:288-95. [CrossRef ]

20. Pieringer H, Labek G, Auersperg V, Böhler N. Cementless total hip ar- throplasty in patients older than 80 years of age. J Bone Joint Surg Br 2003;85:641-5

21. Thakur RR, Deshmukh AJ, Goyal A, Ranawat AS, Rasquinha VJ, Rodriguez JA. Management of failed trochanteric fracture fixation with cementless modular hip arthroplasty using a distally fixing stem. J Arthroplasty 2011;26:398-403. [CrossRef ]

\section{KLINIK ÇALIŞMA - ÖZET}

\section{Yaşlı hastalarda görülen dengesiz intertrokanterik kırıkların tedavisinde, çimentosuz ve çimentolu kalkar replasmanlı hemiartroplastinin karşılaştırılması}

\section{Dr. Deniz Çankaya, Dr. Bülent Özkurt, Dr. Abdullah Yalçın Tabak}

Ankara Numune Eğitim ve Arastırma Hastanesi, Ortopedi ve Travmatoloji Kliniği, Ankara

AMAÇ: Instabil (dengesiz) intertrokanterik femur kırıklarının yaşlılardaki tedavisi, içten tespitteki yüksek başarısızlık oranları nedeniyle halen üzerinde görüş birliği olmayan bir sorundur. Hemiartroplasti, yaşlı hastalarda tercih edilen tedavi seçeneklerinden biridir. Bu çalışmada, yaşlı hastalarda görülen dengesiz intertrokanterik femur kırıkları için, çimentosuz ve çimentolu parsiyel artroplastilerin güvenilirlikleri karşılaştırıldı.

GEREÇ VE YÖNTEM: 2008 ile 2010 yılları arasında AO sınıflamasına göre 31 A2 tipi intertrokanterik femur kırığı olan 86 yaşlı hastaya, çimentosuz $(n=40)$ ve çimentolu $(n=46)$ parsiyel artroplasti uygulandı. Hastaların cerrahi süreleri, kan kayıpları, kan transfüzyonları, Harris kalça skorları, femoral komponentlerin gevşemeleri, hastanede kalma süreleri ve ölüm oranları kaydedildi.

BULGULAR: Gruplar arasında, kan transfüzyonu, hastanede kalış süresi, implant gevşeme oranları, Harris kalça skorları ve takiplerdeki ölüm oranları açısından fark yoktu. Yürüme yeterliliği erken dönemde çimentolu grupta daha iyiydi. Cerrahi zamanı, kan kaybı ve perioperatif ölüm oranları çimentosuz grupta anlamlı derecede düşüktü.

TARTIŞMA: Çimentosuz hemiartroplasti ileri yaş grubundaki hastalarda görülen dengesiz intertrokanterik femur kırıklarının tedavisinde erken mobilizasyona olanak tanımasıyla, kabul edilebilir fonksiyonel sonuçlarıyla, düşük implant gevşeme oranlarıyla, daha kısa cerrahi süresiyle, daha az kanamayla ve daha düşük perioperatif ölüm oranıyla güvenilir bir tedavi seçeneğidir.

Anahtar sözcükler: Çimentosuz hemiartroplasti; ileri yaş; intertrokanterik femur kırığı; yaşlı.

Ulus Travma Acil Cerr Derg 2013;19(6):548-553 doi: 10.5505/tjtes.2013.57615 